\title{
$\mathrm{Al}-\mathrm{Zn}-\mathrm{Mg}$ 系合金の溶接部の応力腐食割れに 及ぼす $\mathrm{Cu}$ の影響
}

\author{
上 門 正 樹* 岡 崎 章 三** \\ 清 重 正 典** 过 本 和 司***
}

\section{The Effect of Copper Addition on Stress Corrosion Cracking in Welds of Al-Zn-Mg Alloys}

by

\section{Masaki UeKadO*, Shozo OKAZAKI**, Masanori KiYoshigE** and Kazushi Tsujimoto***}

An investigation was made on the effect of small amount of $\mathrm{Cu}$ on the stress corrosion cracking in welds of Al- $\mathrm{Zn}-\mathrm{Mg}$ series A7N01 alloys. The environments used were $3.5 \% \mathrm{NaCl}$ solution, $36 \mathrm{~g} / l \mathrm{CrO}_{3}$ $+30 \mathrm{~g} / l \mathrm{~K}_{2} \mathrm{Cr}_{2} \mathrm{O}_{7}+3 \mathrm{~g} / l \mathrm{NaCl}$ solution and atomospheric exposure.

The results obtained are as follows :

The weld heat affected zone has higher susceptibility to stress corrosion cracking than the other position. Stress corrosion cracking fracture principally occurs in the weld heat affected zone about 0.5 $\sim 2 \mathrm{~mm}$ far from the weld bond.

The addition of $\mathrm{Cu}$ increases strongly the resistance to stress corrosion cracking in aged alloys. Especially the addition of $\mathrm{Cu}$ increases the initiation time of stress corrosion cracking, but does not improve so effectively the resistance to crack growth rate $d a / d t$ corresponding to region II. From the practical point of view, it is necessary to add a small amount of $\mathrm{Cu}$ (less than $0.2 \%$ ) to avoid stress corrosion cracking in aged welds of A7N01 alloy.

Key words : Stress corrosion cracking, Al-Zn-Mg alloys, Welds, $\mathrm{Cu}$ addition, Aging

\section{1 緒言}

$\mathrm{Al}-\mathrm{Zn}-\mathrm{Mg}$ 系合金である A7N01 合金は，溶接構造 用材料として広く用いられており，最近特に大型構造 物の軽量化をはかるため, 強度部材としてこの系の合 金の使用が増加している.

$\mathrm{Al}-\mathrm{Zn}-\mathrm{Mg}$ 系合金の実用化にあたって重要な問題 として応力腐食割れがあげられる。この系の合金の溶 接部の内，溶接熱影響部は溶接金属からの距離に応じ てそれぞれ異なった熱履歷を受けるため非常に複雑な 金属組織となり，特に応力腐食割れ感受性に対して各 位置により違ったレベルになっている。 また，実構造 部材では時効等による経年変化によって応力腐食割れ 感受性が低下する場合も考えられる。
この系の合金は, 当初主として溶接性の観点から $\mathrm{Cu}$ を含まない合金が使用されていたが, 最近は溶接 施工技術の向上もあり $\mathrm{Cu}$ を添加した合金も使用され つつある. 一般的にこの系の合金の耐応力腐食割れ性 は $\mathrm{Cu}$ 添加によって改善されることが知られている.

しかしながら，この系の合金の溶接部特に溶接熱影響 部が時効による経年変化を受けた時， $\mathrm{Cu}$ を添加する ことにより耐応力腐食割れ性がどのように異なるかと いう点については十分明らかにされていない.

そこで，本研究では時効した $\mathrm{A} 7 \mathrm{~N} 01$ 合金溶接部の 応力腐食割れに関して，特に $\mathrm{Cu}$ 添加の影響について 検討したので報告する。

\section{2 実 験 方 法}

Table I. Chemical compositions of A7N01 alloys. (wt\%)

\begin{tabular}{c|c|c|c|c|c|c|c|c|c|c|c}
\hline Alloy & $\mathrm{Si}$ & $\mathrm{Fe}$ & $\mathrm{Cu}$ & $\mathrm{Mn}$ & $\mathrm{Mg}$ & $\mathrm{Cr}$ & $\mathrm{Zn}$ & $\mathrm{Zr}$ & $\mathrm{Ti}$ & $\mathrm{V}$ \\
\hline $\mathrm{A}$ & 0.10 & 0.23 & 0.01 & 0.45 & 1.18 & 0.22 & 4.68 & 0.16 & 0.07 & 0.01 \\
B & 0.08 & 0.22 & 0.18 & 0.43 & 1.12 & 0.22 & 4.36 & 0.16 & 0.06 \\
JIS & $\leq 0.30$ & $\leq 0.35$ & $\leq 0.20$ & $0.02 \sim 0.7$ & $1.0 \sim 2.0$ & $\leq 0.30$ & $4.0 \sim 5.0$ & $\leq 0.25$ & $\leq 0.20$ & $\leq 0.10$ \\
\hline
\end{tabular}


Table II. Welding conditions of A7N01 alloys.

\begin{tabular}{|c|c|c|c|c|c|c|c|}
\hline $\begin{array}{l}\text { Welding } \\
\text { process }\end{array}$ & $\begin{array}{l}\text { Electrode } \\
\text { wire }\end{array}$ & $\begin{array}{l}\text { Numbers } \\
\text { of pass }\end{array}$ & $\begin{array}{l}\text { Welding } \\
\text { current } \\
(\mathrm{A})\end{array}$ & $\begin{array}{l}\text { Arc } \\
\text { voltage } \\
\text { (V) }\end{array}$ & $\begin{array}{l}\text { Welding } \\
\text { speed } \\
(\mathrm{mm} / \mathrm{min})\end{array}$ & $\begin{array}{l}\text { Interpass } \\
\text { tempera- } \\
\text { ture }\end{array}$ & Groove shape \\
\hline \multirow{2}{*}{$\begin{array}{l}\text { Automatic } \\
\text { MIG } \\
\text { welding }\end{array}$} & A5356WY & 1 & 230 & 24 & 400 & \multirow{2}{*}{ R.T } & \\
\hline & & 2 & 240 & 28 & 300 & & \\
\hline
\end{tabular}

供試材は，市販の $\mathrm{Al}-\mathrm{Zn}-\mathrm{Mg}$ 系 A7N01-T5 合金押 出形材 $\left(10^{t} \mathrm{~mm}\right)$ であり, その化学組成を Table I に示す．用いた合金は，Cu を添加していない合金 A と JIS 規格の範囲内で $\mathrm{Cu}$ を添加した合金 B の 2 種 類である.これらの合金は, Table IIに示すように電 極ワイヤに A5356WY を用い，自動 MIG 溶接を行っ て溶接継手材を製作した。これらの合金の母材および 溶接材の機械的性質を Table III に示す.なお，溶接 材の引張試験片の形状を Fig. 1(a) に示す.

応力腐食割れ試験は, Fig. 1 (b) (c) に示す試験片を 用いて定ひずみ四点支持曲げ試験およびWOL 試験を 行った.これらの試験には溶接継手材より採取した母 材および溶接材（溶接部を含む）の試験片を用いた.

Table III. Mechanical properties of A7N01 alloys.

\begin{tabular}{c|c|c|c|c|c}
\hline \multirow{2}{*}{ Alloy } & \multicolumn{2}{|c|}{ Sample } & $\begin{array}{c}\sigma_{0.2} \\
\left(\mathrm{kgf} / \mathrm{mm}^{2}\right)\end{array}$ & $\begin{array}{c}\sigma_{\mathrm{B}} \\
\left(\mathrm{kgf} / \mathrm{mm}^{2}\right)\end{array}$ & $\begin{array}{c}\varepsilon \\
\left(\mathrm{kgf} / \mathrm{mm}^{2}\right)\end{array}$ \\
\hline \multirow{3}{*}{ A } & $\begin{array}{c}\text { Base } \\
\text { metal }\end{array}$ & L direction & 22.4 & 31.4 & 19.0 \\
& \multicolumn{2}{|c|}{ LT direction } & 21.9 & 31.5 & 21.3 \\
\cline { 2 - 6 } & \multicolumn{2}{|c|}{ Welding joint } & 17.7 & 27.5 & 6.0 \\
\hline \multirow{2}{*}{ B } & \multirow{2}{*}{ Base } & L direction & 28.0 & 36.6 & 18.0 \\
\cline { 2 - 6 } & metal & LT direction & 28.5 & 36.3 & 19.0 \\
\cline { 2 - 6 } & \multicolumn{2}{|c|}{ Welding joint } & 19.7 & 26.7 & 5.3 \\
\hline
\end{tabular}

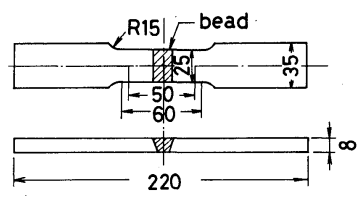

(a) Tensile specimen

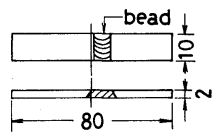

(b) Four-point beam loaded specimen

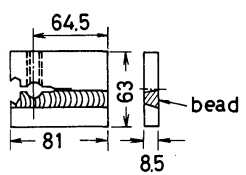

(c) WOL specimen

Fig. 1. Dimensions of tensile test and SCC test specimens $(\mathrm{mm})$.
また, 溶接後溶接材の試験片を最高 $90^{\circ} \mathrm{C}$ までの温度 で所定時間時効を行った試験片（以下時効材と呼ぶ） も作製し実験に供した，試験片の表面は，湿式 1200 番ペーパーで研磨仕上げした。

応力腐食割れ試験雲囲気は, $3.5 \% \mathrm{NaCl}$ 水溶液 $\left(30 \sim 90^{\circ} \mathrm{C}\right)$, ク口ム酸混合水溶液 $\left(36 \mathrm{~g} / l \mathrm{CrO}_{3}, 30\right.$ $\left.\mathrm{g} / l \mathrm{~K}_{2} \mathrm{Cr}_{2} \mathrm{O}_{7}, 3 \mathrm{~g} / l \mathrm{NaCl}, 100^{\circ} \mathrm{C}\right)$ および大気暴露 雾囲気（常温）である.

定ひずみ四点支持曲げ試験では， $0.2 \%$ 耐力以下の 応力に相当するひずみを負荷して試験し, 応力腐食割 れき裂発生までの時間を求めた。 き裂は, 拡大鏡 （×50）で観察し，長さ約 $20 \mu \mathrm{m}$ のき裂が認められた 時間を応力腐食割れき裂発生時間とした. 一方, 応力 腐食割れき裂伝ば試験では, WOL 試験片を用い, 応 力腐食割れ標準試験法に準じて, 疲労予き裂を付与し た後, $K_{\mathrm{I}}=120 \mathrm{kgf} / \mathrm{mm}^{3 / 2}$ を負荷しき裂が停止する まで試験を行った。

\section{3 実験結果および考察}

\section{$3 \cdot 1$ 溶接部の時効特性}

A7N01-T5 合金（合金 A, 合金 B) の溶接後 2 週 間経過した時の溶接部近傍の硬さ分布を Fig. 2 に示す. 合金 $\mathrm{A}$ ，合金 $\mathrm{B}$ ともに溶接金属部の硬さは小さいが, ボンド部近傍の溶接熱影響部は母材より硬さが大きく なっている．また，母材との境界付近では軟化域が生 じており，合金 $\mathrm{A}$ と比べて合金 $\mathrm{B}$ の方がその程度は

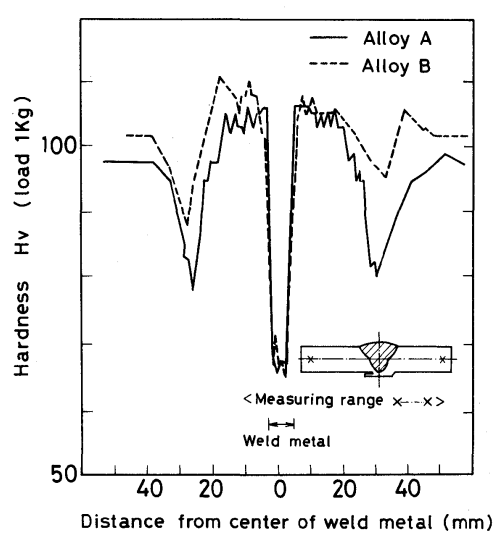

Fig. 2. Hardness distribution of A7N01 alloy welds. 


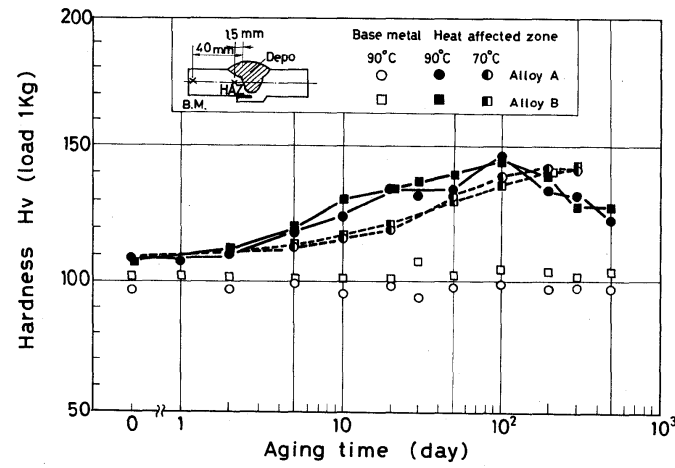

Fig. 3. Hardness-aging time curves of A7N01 alloys aged at $90^{\circ} \mathrm{C}$ and $70^{\circ} \mathrm{C}$.

少ない.これらの溶接材を $90^{\circ} \mathrm{C}$ および $70^{\circ} \mathrm{C}$ で時効 した時の母材および溶接熱影響部（溶接ボンドょり $1.5 \mathrm{~mm}$ 離れた位置）の硬さ変化を Fig. 3 に示す．合 金 $\mathrm{A}$ ，合金 $\mathrm{B}$ ともに溶接熱影響部では時効時間とと もに硬さは上昇し， $90^{\circ} \mathrm{C}$ 時効では 100 日でピークに 達する。これらの硬さの変化は合金 $\mathrm{A}$, 合金 $\mathrm{B}$ でほ

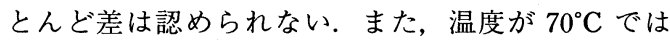
$90^{\circ} \mathrm{C}$ 時効と比べてピークに達する時間が長くなって いる．母材については，いずれの合金も硬さの変化は ほとんど認められず，これはすでに母材が $\mathrm{T} 5$ 処理さ れているためと考えられる.

\section{$3 \cdot 2$ 応力腐食割れき裂発生}

合金 $\mathrm{A}$ の溶接材を $3.5 \% \mathrm{NaCl}\left(30 \sim 90^{\circ} \mathrm{C}\right)$ 中で 定ひずみ四点支持曲げ試験した結果を Fig. 4 に示す.

温度 $30^{\circ} \mathrm{C}$ では $10^{4}$ 時間までき裂は認められなかった が，温度が上昇するほどき裂発生時間は短くなる。し かし, 低応力側では，ほとんど差はなく応力腐食割れ 下限界応力值 $\sigma_{\mathrm{th}}\left(7 \mathrm{kgf} / \mathrm{mm}^{2}\right)$ も温度による影響は 認められなかった．合金 $\mathrm{A}$, 合金 B の母材，溶接材 および時効材を $3.5 \% \mathrm{NaCl}\left(30^{\circ} \mathrm{C}\right)$ 中で定ひずみ四 点支持曲げ試験した結果を Fig. 5 に示す．いずれの合 金も負荷応力レベルにかかわらず $10^{4}$ 時間までき裂の

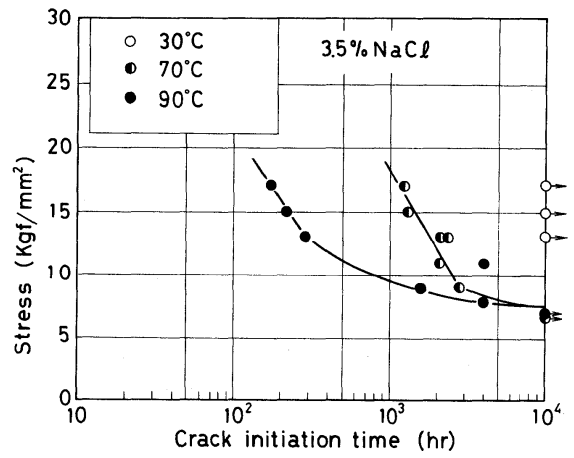

Fig. 4. Effect of solution temperature on crack in itiation time of Alloy A welds in $3.5 \% \mathrm{NaCl}$.

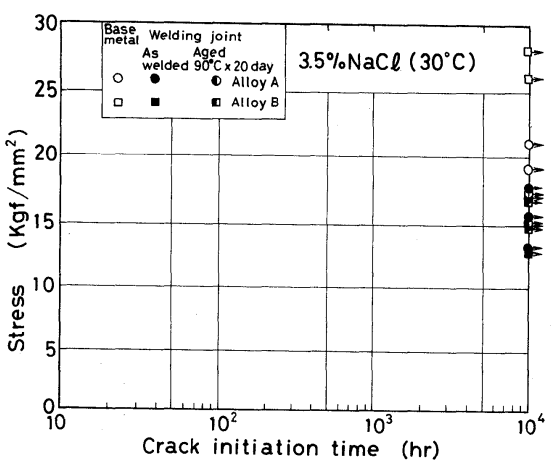

Fig. 5. Applied stress versus crack initation time of A7N01 alloys in $3.5 \% \mathrm{NaCl}\left(30^{\circ} \mathrm{C}\right)$.

発生は認められなかった。 そこで, 溶接材および時効 材を $3.5 \% \mathrm{NaCl}\left(90^{\circ} \mathrm{C}\right)$ 中で定ひずみ四点支持曲げ 試験した．その結果を Fig. 6 に示す．合金 A では, 応力腐食割れき裂を生じたが, $\mathrm{Cu}$ を添加した合金 B では所定の試験時間でき裂は認められず， $\mathrm{Cu}$ 添加の 効果が認められる. 合金 $\mathrm{A}$ の高応力レベルでは溶接 材と比べて時効材のき裂発生時間は短く, 時効時間 50，100 日の時効材でもっともき裂発生時間が短い. 高応力レベルでは, Fig. 3 に示した時効曲線と比較す ると，き裂発生時間と時効による硬化とに相関性があ るが，低応力レベルでは時効時間によってほとんどき 裂発生時間には差はなく, 下限界応力值 $(7 \sim 8$ $\left.\mathrm{kgf} / \mathrm{mm}^{2}\right)$ もほとんど変らなかった。これは, 低応 カレベルでは試験中に過時効状態になったため割れ感 受性に差がなくなったものと考えられる.

また, クロム酸混合水溶液 $\left(100^{\circ} \mathrm{C}\right)$ 中で同様の定 ひずみ四点支持曲げ試験した結果を Table IVに示す. 合金 $\mathrm{A}$ ，合金 $\mathrm{B}$ ともに溶接材ではき裂は発生せず,

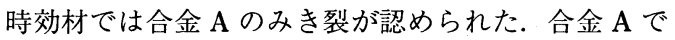
は時効時間 50,100 日の時効材でもっとも応力腐食割 れのき裂発生時間が短くなる傾向が認められた。

つぎに，合金 $\mathrm{A}$ ，合金 $\mathrm{B}$ の母材，溶接材㧍よび時

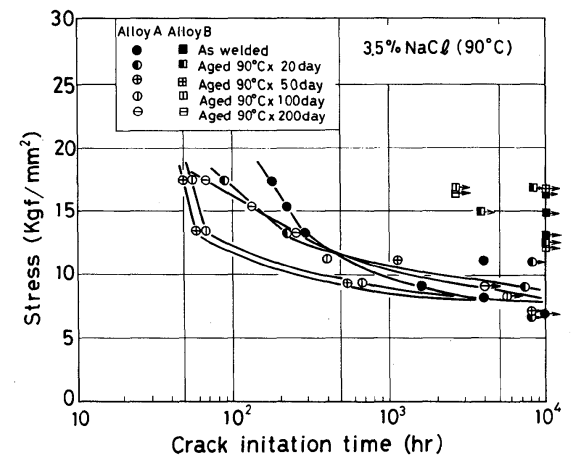

Fig. 6. Applied stress versus crack initiation time of A7N01 alloys in $3.5 \% \mathrm{NaCl}\left(90^{\circ} \mathrm{C}\right)$. 
Table IV. Results of SCC test of A7N01 alloys in a salt-chromate solution.

$\left(36 \mathrm{~g} / l \mathrm{CrO}_{3}, 30 \mathrm{~g} / l \mathrm{~K}_{2} \mathrm{Cr}_{2} \mathrm{O}_{7}, 3 \mathrm{~g} / l \mathrm{NaCl}, 100^{\circ} \mathrm{C}\right)$

\begin{tabular}{|c|c|c|c|c|c|c|c|}
\hline \multirow{2}{*}{\multicolumn{2}{|c|}{ 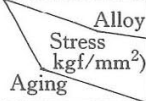 }} & \multicolumn{3}{|c|}{ A } & \multicolumn{3}{|c|}{ B } \\
\hline & & 17 & 13 & 9 & 17 & 13 & 9 \\
\hline \multicolumn{2}{|c|}{ As welded } & 00 & 00 & 00 & 00 & 00 & 00 \\
\hline \multirow{4}{*}{$90^{\circ} \mathrm{C}$} & 20 day & 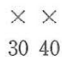 & $\begin{array}{c}\times \times \\
60 \quad 180\end{array}$ & $\begin{array}{r}\times 0 \\
360\end{array}$ & 00 & 00 & 00 \\
\hline & 50 day & $\begin{array}{cc}x & \times \\
20 & 25\end{array}$ & $\begin{array}{cc}\times & \times \\
30 & 60\end{array}$ & $\begin{array}{l}\times \times \\
30 \quad 90\end{array}$ & 00 & 00 & 00 \\
\hline & 100 day & $\begin{array}{ll}\times & \times \\
10 & 10\end{array}$ & $\begin{array}{ll}x & \times \\
20 & 25\end{array}$ & $\begin{array}{ll}x & \times \\
30 & 40\end{array}$ & 00 & 00 & 00 \\
\hline & 200 day & $\begin{array}{l}\times \quad \times \\
1020\end{array}$ & $\begin{array}{c}\times \times \\
20120\end{array}$ & $\begin{array}{cc}\times & \times \\
120 & 240\end{array}$ & 00 & 00 & 00 \\
\hline
\end{tabular}

O No crack $(360 \mathrm{~min}$.

$\times$ Cracks (a number: crack initiation time, $\min$ )

効材の大気暴露下に打ける応力腐食割狆試験結果を Fig. 7 に示す，大気暴露下に扔いても合金 Aでは応力 腐食割れき裂を生じたが，合金 Bではき裂は認めら

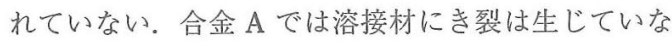
いが，時効材でき裂が発生しており，50，100日の時 効材でもっとも応力腐食割れき裂発生時間が短くなっ ている。この $90^{\circ} \mathrm{C} \times 50$ 日㧍よび 100 日時效材の下限 界応力值は $7 \mathrm{kgf} / \mathrm{mm}^{2}$ 程度である。このように大気 暴露下に扔ける応力腐食割れき裂発生の傾向は前述し た二つの促進試験結果 $(3.5 \% \mathrm{NaCl}$ ，クロム酸混合

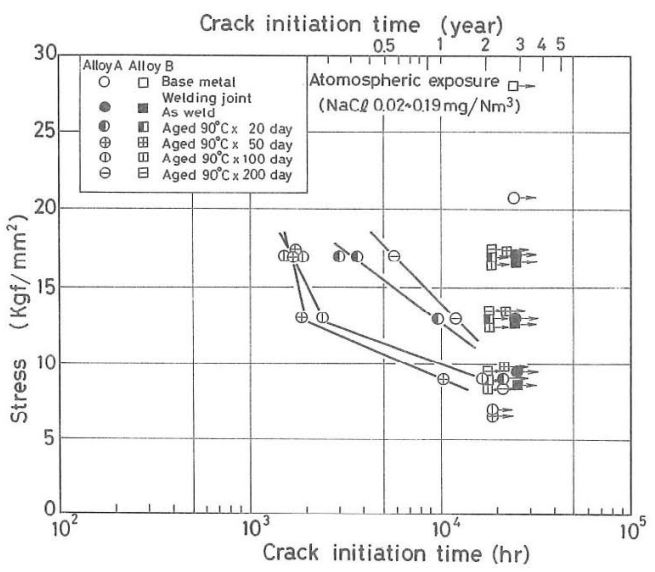

Fig. 7. Applied stress versus crack initiation time of A7N01 alloys in atomospheric exposure.

水溶液）と良く一致している。

合金 $\mathrm{A}$ の時効材 $\left(90^{\circ} \mathrm{C} \times 100\right.$ 日時効）の各種雲囲 気下に扔ける応力腐食割れき裂発生の状況を Fig. 8 に 示す、いずれの雲囲気下に扔いても試験片の表面に孔 食が認められ，それを起点として応力負荷方向に直角 にき裂が発生している。合金 $\mathrm{A}$ の時効材の $3.5 \%$ $\mathrm{NaCl}$ 水溶液 $\left(90^{\circ} \mathrm{C}\right)$ 中に扔けるき裂の断面の光学顕 微鏡観察結果を Fig. 9 に示す。試験片の溶接熱影響部 では，多数の溝状の孔食が認められ，これらの一部よ り応力腐食割れき裂を生じている。合金 Bでは，合
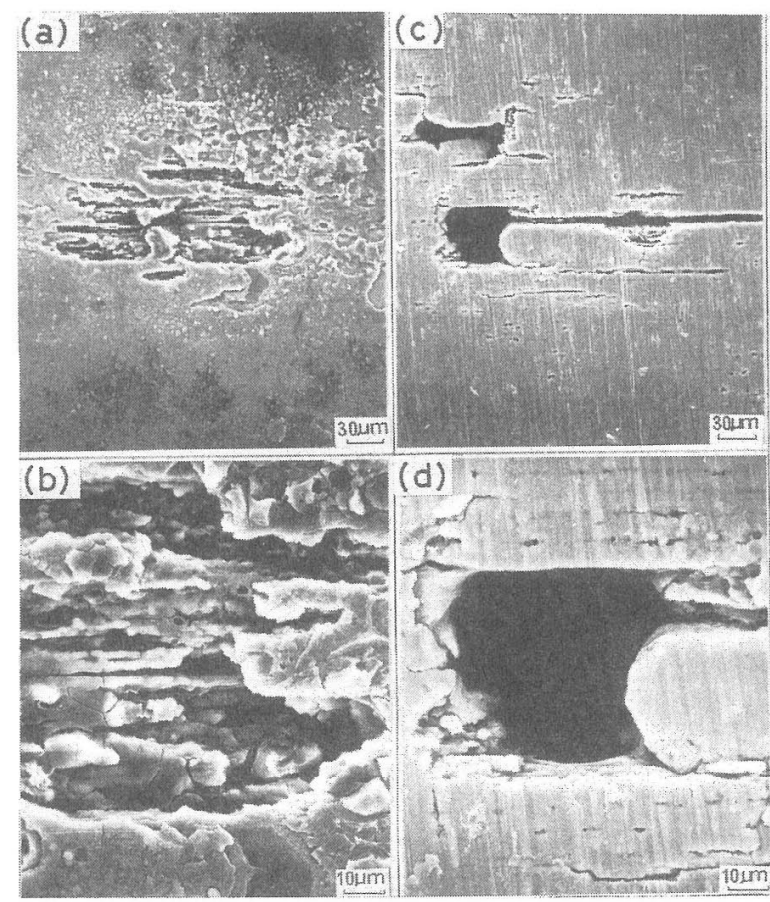

(a)(b) $3.5 \% \mathrm{NaCl}$ solution $\left(90^{\circ} \mathrm{C}\right)$

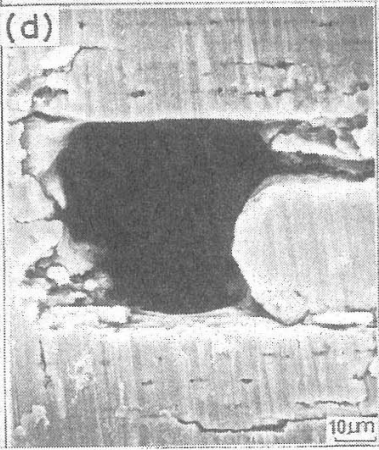

(c)Xd) Salt-chromate sulution $\left(100^{\circ} \mathrm{C}\right)$.
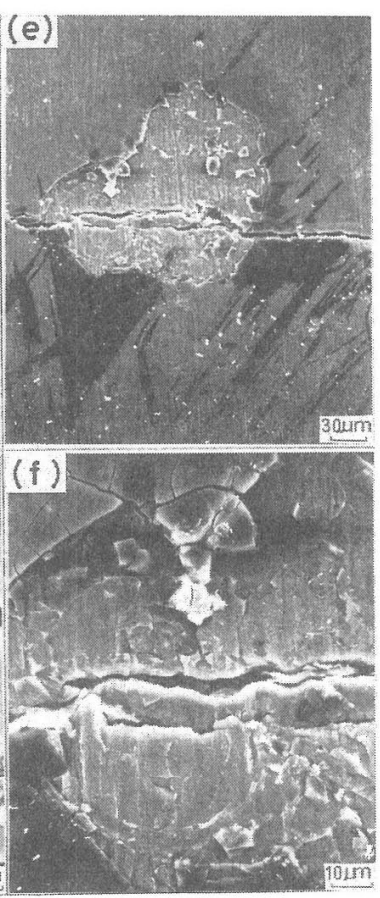

(e)(f) Atomospheric exposure.

Fig. 8. Crack initiated at corrosion pits of Alloy A (Aged $90^{\circ} \mathrm{C} \times 100$ day, $\sigma: 17 \mathrm{~kg} / \mathrm{mm}^{2}$ ). 


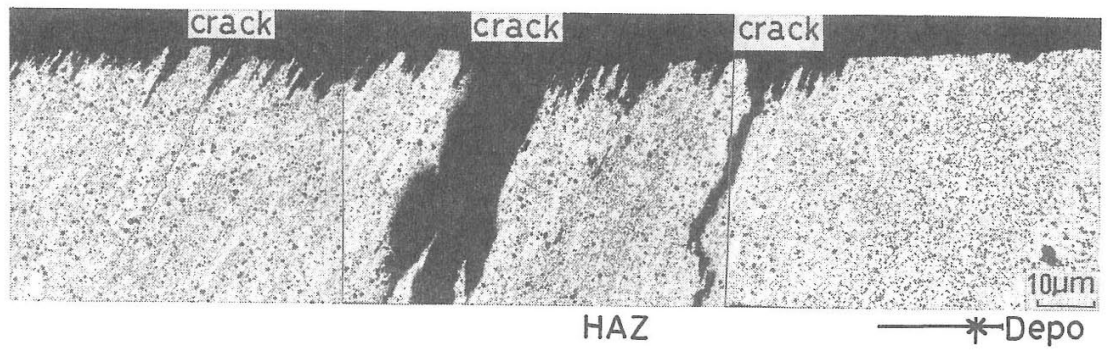

Fig. 9. Microstructure showing stress corrosion cracking in $3.5 \% \mathrm{NaCl}$ solution of Alloy A (as welded, $\sigma: 17 \mathrm{kgf} / \mathrm{mm}^{2}$ ).

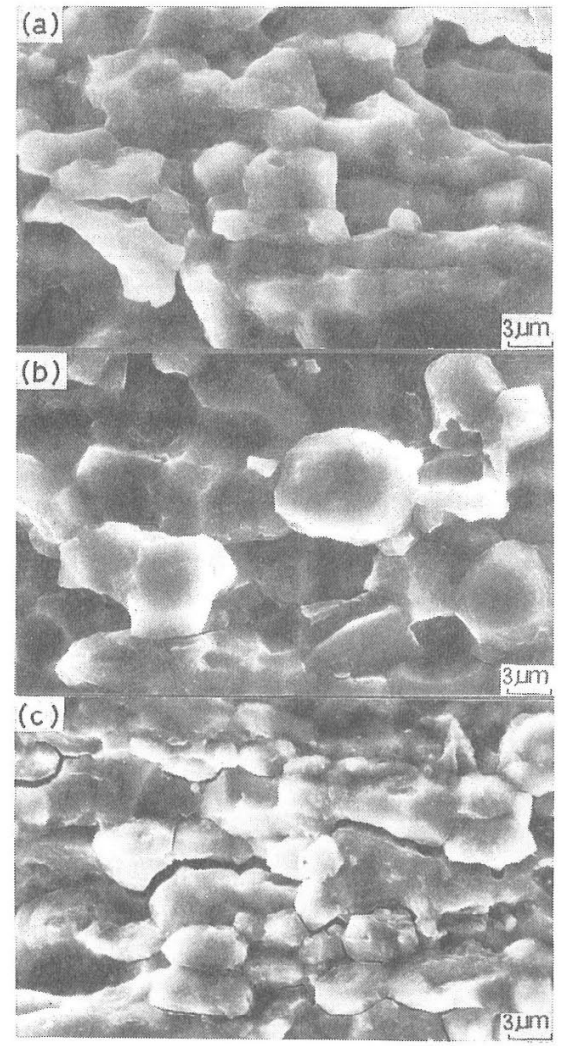

(a) $3.5 \% \mathrm{NaCl}$ solution $\left(90^{\circ} \mathrm{C}\right)$.

(b) Salt-chromate solution $\left(100^{\circ} \mathrm{C}\right)$.

(c) Atomospheric exposure.

Fig. 10. Fractographs showing the area near stress corrosion cracking initiation of Alloy A (Aged $90^{\circ} \mathrm{C} \times 100$ day, $\sigma: 17 \mathrm{kgf} / \mathrm{mm}^{2}$ ).

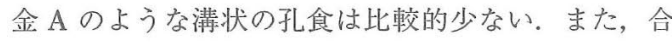
金 $\mathrm{A}$ の時効材 $\left(90^{\circ} \mathrm{C} \times 100\right.$ 日時効）の各種雲囲気下 における応力腐食割れき裂の起点部近傍の破面を Fig. 10 に示す。いずれも粒界割れを呈しておりっこれら の雲囲気下での破壊形態は類似している。

\section{$3 \cdot 3$ 応力腐食割れき裂伝ぱ}

合金 $\mathrm{A}$, 合金 $\mathrm{B}$ の溶接材の $3.5 \% \mathrm{NaCl}$ 水溶液（90, $\left.70^{\circ} \mathrm{C}\right)$ 中における $K_{1}-d a / d t$ の関係を Fig. 11 に示 す。温度 $90^{\circ} \mathrm{C}$ では, 合金 $\mathrm{A}$ と合金 $\mathrm{B}$ の領域 II のき

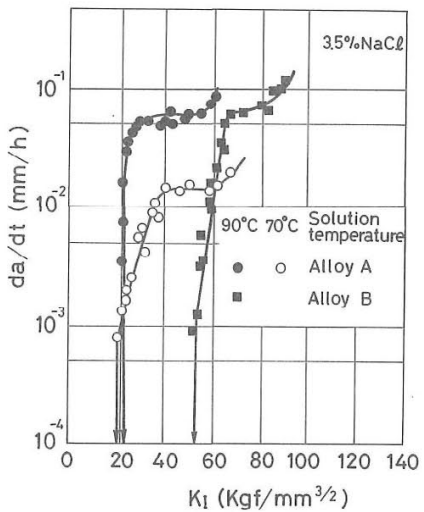

Fig. 11. SCC growth-rate versus stress intensity of A7N01 alloy welds.

裂伝ぱ速度はほとんど差はないが，下限界応力拡大係 数 $K_{\mathrm{Iscc}}$ は合金 $\mathrm{A}$ が $23.1 \mathrm{kgf} / \mathrm{mm}^{3 / 2}$ で合金 B が 53.0 $\mathrm{kgf} / \mathrm{mm}^{3 / 2}$ となり, 合金 B の方が大きい值を示す.

つまり，Cu を添加することによりき裂が伝ぱしはじ める $K_{I}$ 值は大きくなるが，いったんき裂が進展しは じめると $\mathrm{Cu} の$ 添加にかかわらずほほ同じ伝ぱ速度を 示す。また，合金 A に関する試験温度の影響につい ては，領域Iのき裂伝ぱ速度は $90^{\circ} \mathrm{C}$ と比べて $70^{\circ} \mathrm{C}$ では小さくなるが, $K_{\mathrm{ISCC}}$ は $90^{\circ} \mathrm{C}$ の場合 23.1 $\mathrm{kgf} / \mathrm{mm}^{3 / 2}$ で $70^{\circ} \mathrm{C}$ の場合 $19.3 \mathrm{kgf} / \mathrm{mm}^{3 / 2}$ となり, ほとんど差はなかった。

つぎに，合金 A の溶接材抢よび時効材の $3.5 \%$ $\mathrm{NaCl}$ 水溶液 $\left(90^{\circ} \mathrm{C}\right)$ 中での $K_{\mathrm{I}}-d a / d t$ の関係を Fig. 12 に示す。時効材では時效時間による $K_{\mathrm{ISCC}}$, $d a / d t$ はほとんど変らないが, 溶接材では $K_{\mathrm{I}}$ 值に依 存しない領域 Iのき裂伝ぱ速度の範囲が広い。これは, 溶接材の場合, 試験温度が $90^{\circ} \mathrm{C}$ と高く試験中に時効 が進行し, 領域】のき裂伝ぱ速度が低下せずに進展し たものと考えられる。

なお，大気暴露下での試験 $\left(2 \times 10^{4}\right.$ 時間 $)$ では, またきき裂が停止していないので，あくまで参考值では あるが，3.5\% $\mathrm{NaCl}\left(90^{\circ} \mathrm{C}\right)$ の場合と同様合金 $\mathrm{B}$ の 方が合金 Aより大きな $K_{\mathrm{ISCC}}$ を示すようである。

\section{$3 \cdot 4$ 応力腐食割れに及ぼす $\mathrm{Cu}$ 添加の効果}




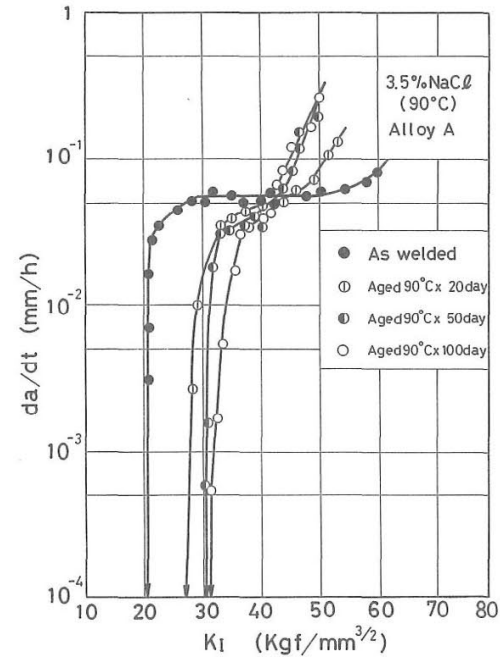

Fig. 12. SCC growth-rate versus stress intensity of Alloy A.

応力腐食割れに及ほすす $\mathrm{Cu}$ 添加の影響は，特に応力 腐食割れき裂発生に関与しており，その発生寿命を著 しく改善させることが明らかとなった。

応力腐食割れのき裂は，主として溶接ボンドより 0.5 ～ $2 \mathrm{~mm}$ 離れた位置で生じており，硬さ分布から して最高硬さ付近に相当している。 そこで，溶接ボン ドより $1.5 \mathrm{~mm}$ 離れた位置の金属組織を調べた。薄膜 による透過型電子顕微鏡写真を Fig. 13 に示す. 巨大 な粒子は， $\mathrm{Fe} ， \mathrm{Si}$ 等の不純物元素および $\mathrm{Cr}, \mathrm{Mn}$, $\mathrm{Zr}$ 等の微量添加元素による不溶性化合物と考えられ
る。溶接のままの状態では合金 A と比べて合金 B で は結晶粒界にすでに析出物が生じているのが認められ る. $90^{\circ} \mathrm{C} \times 20$ 日時效材では，GP ゾーン以外に結晶 㑊界に $\eta$ 相 $\left(\mathrm{MgZn}_{2}\right)$ が析出し，粒内では微細な $\eta^{\prime}$ 相が認められ, 結晶粒界近傍に無析出带 PFZが生じ ている。合金 A と比べて合金 Bの方が，粒界および 粒内析出物は大きい. $90^{\circ} \mathrm{C} \times 100$ 日時效材では，合金 $\mathrm{A}$ と合金 B の差は台らに大きくなっており，特に結 晶粒界の析出物の大きさが合金 $\mathrm{A}$ と比べて合金 B の 方が大きく，比較的密な分布状態になっている。

従来より応力腐食割れに及ほす金属組織として結晶 粒界析出物, PFZ 年幅, 粒内析出物等について研究 されているが，応力腐食割れ感受性との関係は必ずし も明確にされていない。本研究結果からすると PFZ の幅は， $90^{\circ} \mathrm{C} \times 100$ 日時效材で合金 $\mathrm{A}$ は $600 \AA$ ，合金 B は $700 \AA$ 程度でそれほど大きな差は認められなかっ た。

応力腐食割れのき裂発生状況の観察によると, 孔食 のような局部的な腐食がき裂発生の起点になっている ことから，少なくともき裂発生に関して腐食溶解が支 配的に作用していると思われる。通常，この種の合金 では結晶粒界には $\eta$ 相が析出し，これは電気化学的 に卑な析出物であり，粒界近傍は逆に固溶 $\mathrm{Zn}$ 量が少 なくなるため粒内と比べて貴になる。合金 A では, 結晶粒界の析出物が溶解されやすいことによりき裂発 生を助長したものと考えられる。一方，合金 B は $3.5 \% \mathrm{NaCl}$ 水溶液 $\left(90^{\circ} \mathrm{C}\right)$ 中で合金 $\mathrm{A}$ と比較して粒 界に沿った溝状の孔食が少ないことから，Cu を添加

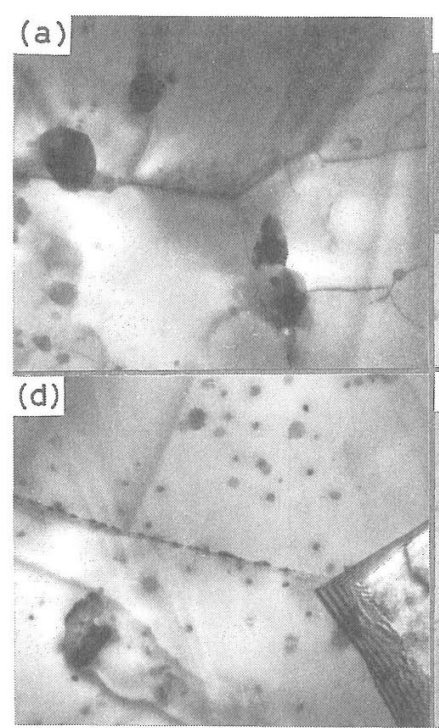

(a) Alloy A as welded. (d) Alloy B as welded.

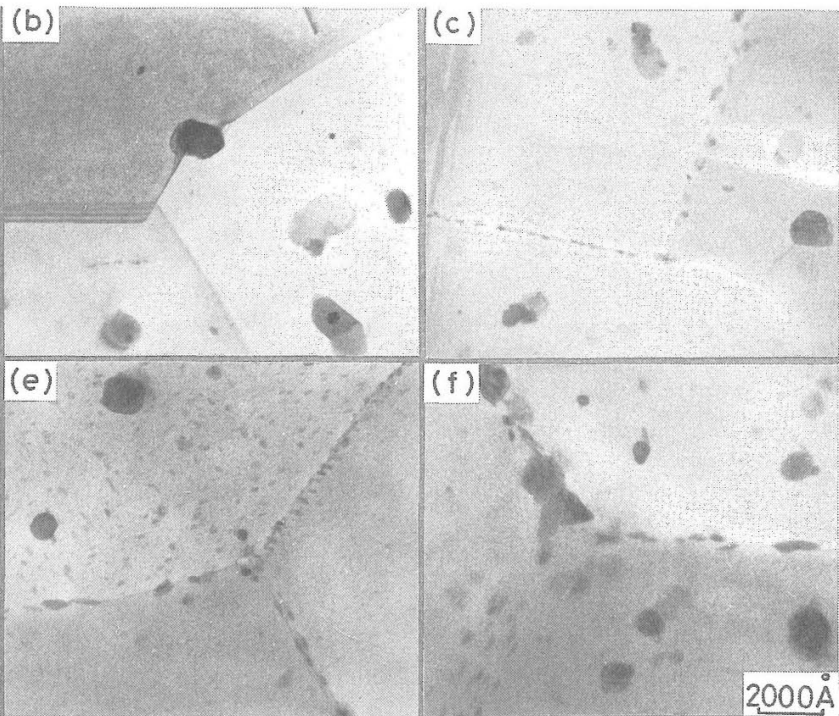

(b) Alloy A aged at $90^{\circ} \mathrm{C}$ for 20 day. (c) Alloy $\mathrm{B}$ aged at $90^{\circ} \mathrm{C}$ for 20 day. (c) Alloy $\mathrm{A}$ aged at $90^{\circ} \mathrm{C}$ for 100 day. (f) Alloy $\mathrm{B}$ aged at $90^{\circ} \mathrm{C}$ for 100 day.

Fig. 13. Transmission electron micrographs in heat affected zone (1.5 mm from bond) of A7N01 alloys. 
すると粒界の析出物にも $\mathrm{Cu}$ が移行することにより， 粒内との電位差が小さくなり粒界の選択的な腐食傾向 が少なくなるためき裂発生が抑制されたものと考えら れる.

\section{4 結言}

A7N01-T5 合金溶接部の酎応力腐食割れ性に及ぼ す $\mathrm{Cu}$ 添加の影響について検討した結果, 次のことが 明らかとなった。

（1）時効の影響を受けなければ， $\mathrm{Cu}$ を添加しない 合金でも酎応力腐食割れ性に問題はないが，時効を受 ける場合には $\mathrm{Cu}$ を添加した合金の方が耐応力腐食割 れ性が著しく改善される.

（2）時効材に関して Cu 添加の改善効果は, 応力腐 食割れき裂発生に寄与しており,き裂伝ぱの下限界応 力拡大係数 $K_{\mathrm{IScc}}$ は $\mathrm{Cu}$ を添加した合金の方が大きい が，領域 II のき裂伝ぱ速度は $\mathrm{Cu}$ 添加によってもほと んど差は認められなかった。

（昭和62年 3 月13日 腐食防食部門委員会第137回例会にて講演）

\section{参考 文 献}

1 ）馬場義雄, 高島 章, 住友軽金属技報, 16, 60（1975).

2 ）圓城敏男, 黒田敏雄, 材料, 29, 617 (1980).

3 ) J. M. Truscott, V. E. Carter and H. S. Campbell, J. Inst. Metals 99, 57 (1971).

4 ）村上陽太郎，防食技術，26，245（1977）.

5 ) J. Busby, J. F. Cleave and R. L. Cudd, J. Inst, Metals, 99, 41 (1971).

6 ）宮木美光, 平野正和, 神戸製鋼技報, 26, 80 (1976).

7 ) 当摩 建, 高橋憲昭, 竹内 庸, 軽金属, 33, 377 (1983).

8 ) 斎藤寿雄, 田中孝一, 軽金属, 22, 403 (1972).

9 ) 学振129委員会, “応力腐食割れ標準試験法” (1985).

10) A. J. Cornish and M. K. B. Day, J. Inst. Metals, 99, 377 (1971).

11) N. Ryum and K. Barrdseth, J. Inst. Metals, 96, 92, (1968).

12) B. C. Peter, J. Inst. Metals, 99, 354 (1971).

13) K. G. Kent, J. Inst, Metals, 97, 127 (1969).

14) H. A. Holl, Corrosion, 23, 173 (1967).

15）宮本 学, 村上陽太郎, 日本金属学会誌, 37, 394 (1973). 